\title{
Sensual Love and Ficinian Tradition in Psafone by Melchiorre Zoppio (1590)
}

The numerous treatises on love written in Italy during the Renaissance testify to the central importance of Marsilio Ficino's philosophy. Ficino's seminal Commentary on Plato's Symposium, written in Latin in 1469 and translated into Italian by Ficino himself in 1474, gave birth to a rich and fascinating genre which lasted until the beginning of the seventeenth century. Both literature and philosophy reflected Ficino's complex theorization of sensual passions and mystical contemplation. Mario Equicola, Leone Ebreo, Pietro Bembo, Baldassar Castiglione are only a few of the numerous authors who discussed and challenged Ficino's theories. However, as Eugenio Garin observes, at the end of the sixteenth century most of the Italian treatises failed to introduce any new element in the philosophical debate on love and simply repeated trite ideas and concepts (Garin 2.581-615).

Although few texts succeeded in formulating a coherent and original theorization on love. many of them expressed an often remarkable originality either in specific areas of this philosophical tradition or in their literary structure. For instance, even though Sperone Speroni's Dialogo d'amore (1542) neither questions nor rejects any of Ficino's theories, its analysis of the multiple effects of jealousy makes it one of the most moving works of the century. Guido Casoni's Della magia d'amore (1592), another neglected text of this genre, offers an engrossing discussion on how sight affects human passions (Maggi, "Della magia"). In other words, instead of projecting our modern view of philosophical writing onto the Ficinian tradition, we must analyze this Renaissance genre as a hybrid one, blending both literature and philosophy. If we do so, several of the sixteenth-century treatises on love, its origin and its effects, acquire an indisputable relevance.

One of the least-known texts of the Italian tradition of trattati d'amore (treatises on love) is Psafone (1590) by Melchiorre Zoppio, founder of the "Academy of the Frozen" (Accademia dei Gelati) in Bologna in 1588. ' Zoppio was born in Bologna in 1534 and died in 1591. Like his father Girolamo, Melchiorre Zoppio was a prolific author of tragedies. However, his intellectual interest focused on the academy that he himself founded (Tiraboschi 8.329). The "Accademia dei Gelati," one of the most productive and famous in the late 
Renaissance, lasted for more than two centuries (Maylender 3.81). The members of the academy gathered at Zoppio's house, in a marvelous room with a theater and a rich library. The subjects of the first meetings were erotic poetry and the Neoplatonic philosophy of love (Maylender 3.83). Later, the Academy developed a great interest in philosophy. Following Plato's philosophical gatherings, the "frozen" academicians discussed the most subtle philosophical issues after a friendly dinner. They called these meetings "Cene de' saggi" (dinners of wise men). The name of the Academy refers to the academicians' belief that their conversations would "enflame" their "frozen" intellects (Maylender 3.82). In 1590, two years after its founding, the Academy published its first volume, divided into two parts. The first section is Ricreazioni amorose degli Accademici Gelati di Bologna, an anthology of love poetry consisting of each academician's canzoniere, and Psafone, Zoppio's treatise on love. In Ricreazioni amorose each "frozen" academician, whose actual identity hides behind an adjective describing a central aspect of his character such as "l'illuminato" (the enlightened one) or "l'oscuro" (the obscure one), introduces his poetry with an emblematic picture, the so-called impresa (device). Other academies, such as "L'Accademia degli Occulti" (The Academy of the Unknown) of Brescia, had composed a similar "collective" canzoniere. In Rime degli accademici occulti (Brescia 1568), however, each impresa was followed both by a series of sonnets and by an exegesis of each impresa itself.

An impresa is usually composed of a two-, or maximum three-figure picture and a motto inserted in the picture itself. The goal of an impresa is to show the academician's intellectual and spiritual project without revealing it. According to Italian treatises on emblems and imprese of the 15th and 16th century, an impresa is intrinsically different from an emblem. Whereas an emblem expresses a universal concept, such as bravery or honesty, an impresa communicates a personal, private feeling, like desire, love or jealousy. Moreover, whereas an emblem manifests its content in a clear and intelligible manner, an impresa at once protects the subject's emotion and exposes it to the "world"s view. This essential distinction derives from Marsilio Ficino's interpretation of the Egyptian hieroglyphics that had been brought to Italy in the second half of the fifteenth century.

In Ricreazioni amorose degli Accademici Gelati di Bologna, the first part of the book, Melchiorre Zoppio's impresa shows a dark cloud illuminated by the rays of the sun. The motto is "Muneris hoc tui." Zoppio"s "academic name" is "Caliginoso" (foggy, dark). The impresa is followed by Zoppio"s verses dedicated to his beloved, which actually occupy a considerable part of the entire Ricreazioni amorose (64-96). In fact, we might consider Zoppio's love poetry and his subsequent treatise as two chapters of the same text. However, Ricreazioni amorose and $P$ safone express two rather different interpretations of love's meaning and effects. 
In Ricreazioni amorose Zoppio follows the most conventional views on erotic passion. For that matter, let us read the first sonnet of his canzoniere which at once comments upon his impresa and summarizes his theoretical perception of love:

Nube son io che tempestosa e nera minaccia dileguarsi in nembo orrendo, ma se 'l mio sol, con l'aurea luce ardendo m'irraggia, o in su 'l mattino o in su la sera,

viemmi dai rai dell'infiammata sfera vampa, onde onore inusitato apprendo. Nel proprio orror dell'altrui luce splendo, sì ch"io imito del sol la faccia vera.

Ne la beltà che in me raddoppia il suo sembiante, in lei, quanto in altrui, si mira. nel mio proprio squallor più si detesta.

Son io, son quell 'in cui si manifesta donna, il tuo volto. Io son quel che s'ammira; ma l'orrore è pur mio, l'onore il tuo. (64)

The poet is a dark cloud which "threatens to fade away into a horrible tempest," meaning that his identity is an obscure nothingness, a presence with no substance. By reflecting the other's, that is, the beloved 's "golden rays," the cloud/ poet acquires a consistency, a "luminous knowledge" of himself. The poet is nothing but a mirror of his woman's beautiful face; she sees herself in his dark surface/cloud. It is almost superfluous to underscore that in this programmatic sonnet the poet limits himself to reiterating conventional topoi of the Neoplatonic concept of love. In the third book of Dialoghi d'amore Leone Ebreo holds that "la luce del sole non è accidente, ma forma spirituale sua, dependente e formata da luce intellettuale e divina" (182). Like the sun's intellectual and divine light, Zoppio's beloved both illuminates and enlightens her lover. According to Leone Ebreo, human eyes share similar characteristics with the sun, both in its physical and divine nature:

Adunque così come ne l'uomo (che è piccol mondo) l'occhio, fra tutte le sue parti corporee, è come l'intelletto fra tutte le virtù dell' anima, simulacro e seguace di quella. così nel gran mondo il sole fra tutti i corporali è come l'intelletto divino fra tutti gli spirituali, suo simulacro e suo vero seguace $[\ldots]$ E veramente gran simiglianza hanno l'intelletto umano e l'occhio corporeo con l'intelletto divino e col sole. (184-85)

In other words, in the act of composing a love poem Zoppio cannot help but reinforce the traditional view on love and its manifestations. Poetic form 
evokes a certain standardized content. Rhymes and hendecasyllables, one might say, entail a given narrativity. The rest of Zoppio's canzoniere reiterates the same clichéd ideas about the beloved's cruelty, her insensitivity, and her almost divine essence. As he states in his third sonnet, Zoppio's poetry aims to praise and revere his woman's beauty and to proclaim the divine nature of his passion:

Sappia la terra e 'l cielo, e non s'asconda

a gente un mondo ancor da noi divisa,

e 'l più lontan che puote eco risponda

s'io amo, e quanto, e quale, ed in qual guisa.

lo amo. E sì, che pria della gioconda

sua radice la vita andrà recisa,

ch'io cessi amar. E sì, che non profonda

piaga, com'ha il mio cuor, han gli altri incisa.

Amo una Pasithea. L'amo in quei modi

che le forme sì belle e sì divine

si ponno amar: con riverenza e lodi.

Ascoltimi chi può, né alcun confine

la voce mia della sua gloria frodi,

ch'alt'amor, l'oggett'alto onesto ha il fine. (65)

Particularly significant is the fourth sonnet, which revolves around the beloved's physical beauty. As we shall see in Psafone, love's physicality is essential to Zoppio's concept of love. Whereas in Psafone love is primarily a sexual experience, in Ricreationi amorose love is still a Neoplatonic feeling. Following the Petrarchian tradition in his poem Zoppio claims that female beauty transcends any possible description. His woman's beauty is nothing but an expression of the divinity himself:

Le miro in volto un non so che di grande ch'esplicar non si può, veggio un sereno ch'invaghisce, un ardor provo che incendo.

Scrivine quanto puoi, fia sempre il meno. (66)

A similar standpoint is present throughout Zoppio's canzoniere: "Stupisco, e come di Medusa al volto/presente, io sto di me medesmo fuora" (74); "Donna casta e gentil mi fa palese / un pensiero ch'Amor desta in lei pio / di ricompensa al suo gradito amante" (80); "Non mi crede Madonna, ahi non mi crede. / Lasso, che far poss'io? Scoppiar? Morire?" (84).

Strikingly different is the message that Zoppio conveys in Psafone. Trattato d'amore del medesimo calaginoso gelato Melchiorre Zoppio. According to 
Zoppio, love is nothing but a lie. To clarify his point, in the preface Zoppio refers to the myth of Psafone, an African man who wished to be considered a god. To do so, he trained a number of birds to repeat the sentence "gran dio Psafone" (5). Very soon, every bird in his country passively repeated the same "foolish lie." Psafone, Zoppio says, signifies human love; his birds are those men who believe that love is actually a divinity (6).

The idea that love is nothing but a painful and meaningless occurrence is not original. In Ragionamento d'amore (Mantua 1545) Francesco Sansovino stresses the very same concept at the beginning of his text. The wise and old Panfilo says to his young friend Silio:

Tu, che sei giovane, non sai come vanno le cose del mondo. Però avvertisci che quest'accidente, ch 'è infuso nei cuori di tutti coloro che vivano [sic], di tutte le creature, da noi chiamato "amore", è più degno di vituperio in un vecchio che in un giovane. Perché quell'età, che col mezzo di molti anni ha veduto quel che è degno nella vita mortale di biasimo e quel che merita lode, attenendosi alla miglior parte, ci debbe dar essempio di sé non con operazion fanciullesche, ma con costumi degni e convenienti all animo nostro, accioché noi a qualche tempo con l'esser nostro possiamo giovare alla patria, agli amici e alla casa. (153-54)

In the still unpublished Ragionamento d'amore, a discourse delivered at the Academy of Florence in the second half of the sixteenth century, Lorenzo Giacomino de' Tebalducci Malespini vehemently attacks Florentine Neoplatonism:

Che la bellezza sia cosa santa e sacra, che nessun bello sia vizioso, che l'amore di donne belle sia amore divino sono tanto evidenti e manifeste menzogne che è maraviglia che si sia trovato chi abbia tanto ardire di affermarle ed il prender fatica a confutarle saria poco minor vanità della vanità d'averle detto $[$ sic $]$. (6v)

Malespini's entire text aims to confute Ficino's theories of divine and human love (Maggi, "La negatività"). ${ }^{2}$ Young men should spend their time working out, studying the classics, meditating, in a word doing everything they can in order to avoid erotic passion.

Although in his verses Zoppio had stated that love was a divine manifestation and his woman was a sort of goddess, in Psafone he refutes these traditional opinions. In other words, Zoppio passes from the Neoplatonic notion of love to an anti-platonic conception. As Zoppio himself explains in the introduction, Psafone is divided into four sections:

Chi sia questo Amore. Indi $[\ldots]$ qual sia il suo obietto. Poi [...] i modi di acquistarlo e nutricarlo. Ultimamente $[\ldots]$ i soggetti facili ad essere irretiti negli amorosi lacci, ed insieme nei canti loro, gli effetti dell'istesso Amore. (8) 
In the first part of Psafone (9-50) Zoppio warns the reader against the risks of love. Love is an unpredictable and dangerous event; love equals fate (17; 25 ; 33-34). In the first chapter Zoppio does not express any original interpretation of love. Echoing Ficino's definition, Pozzio holds that "Amore è atto di potenza conoscitiva. Diciamo che nell' anima nostra son tre modi di conoscere, col senso, con la ragione, con l'intelletto; dal senso nasce l'incitamento, dalla ragione la elezione, dall'intelletto la volontà" (43).

It is in the final pages of the first chapter that Zoppio expresses a more personal, and quite original, interpretation of love. It is interesting to notice how $P$ safone constantly oscillates between a trite repetition of "received ideas" about love and a refutation of those very ideas. In other words, Zoppio cannot help but use Neoplatonic rhetoric and terminology even when he directly or indirectly denies its validity. Before concluding the first section, Zoppio describes the well-known condition of two lovers who cannot live apart. Zoppio uses the term "furore amatorio." However, whereas in the Platonic and Neoplatonic tradition "furore" has a distinctly religious connotation, in Psafone it simply refers to the lovers' unquenchable desire:

il furore amatorio, com 'ha una volta occupato ed infiammato un uomo, non è musa, non è cantare, non è mutar di luogo che lo rimuova; ma gli innamorati s'amano presenti, si bramano quando sono assenti, si seguitano di giorno, vegliano di notte alle porte, nella sobrietà si chiamano, bevuto c'hanno si cantano. (47)

In Psafone the crucial term "furore" does not indicate a divine possession, but rather a totally human drive. Of course. Ficino"s complex theorization of love and divine enlightenment through desire has no actual connection with Zoppio's treatise on love. The concept is not uncommon in the Italian tradition of trattati d'amore. We have already mentioned two books attacking Neo-platonic love. Whereas for Ficino love was primarily a form of mystical contemplation inspired by a "beautiful form," for other Italian theoricians any notion of love must come to grips with man "s physicality. In the second speech of his Commentary on Plato's Symposium Ficino stresses that "bodies are the shadows and signs of souls and minds" (48). True love, Ficino holds, is exclusively directed to the soul's beloved.

Zoppio apparently maintains Ficino's philosophical structure. The second part of $P$ safone opens with a vaguely Ficinian distinction among three forms of love:

essendo Amore un certo appetito, quante sorti d'appetiti saranno, tante ne porremo d'Amore. Evvi un appetito naturale, il qual seguita non l'apprensione, ma la propensione dell'appetente, sì come della pietra il desiderare il centro, e questo impropriamente e metaforicamente è detto Amore. Evvi un altro appetito animale, i] qual seguita la apprension dell' appetente, ma con necessità, e questo è nei bruti, i quali con tutto che 
non si muovano, se non per oggetti conosciuti, nondimeno ciò non fanno per propria deliberazione [...] E questo si chiama alquanto più propriamente Amore. Vi è per ultimo l'appetito ragionevole, il qual seguita l'apprensione secondo il libero giudicio spettante alla volontà deliberante sopra le sue operazioni. (51-52)

The idea of a three-fold love derives from Ficino's concept of "Venerean daemon":

The Venerean daemon is a three-fold love. The first is placed $[\ldots]$ in the heavenly Venus, that is, in the intelligence itself of the Angelic Mind. The second in the vulgar Venus, that is, in that power of procreation which the World Soul possesses [...] The third order is of the daemons who are the companions of the planet of Venus. (113)

However, a central distinction must be drawn between Zoppio's and Ficino's concept of a three-fold love. Ficino essentially distinguishes between a spiritual love, both in its heavenly and human form. and a carnal one, that is, "bestial" copulation. Heavenly love is in fact a synonym for contemplation. For Zoppio, on the contrary, the three forms of love differ from each other only from a psychological standpoint. As Zoppio repeats several times in the above passage from Psafone, love is essentially a "drive" (appetito).

Zoppio uses a three-fold distinction also when he comes to analyze man's soul:

nell' anima nostra son tre modi di conoscere, col senso, con la ragione, con l'intelletto; dal senso nasce l'incitamento, dalla ragione l'elezione, dall'intelletto la volontà, per cagione del senso comunichiamo co' bruti, per l'intelletto con gli Angeli, rimane in mezzo la ragione propria dell'uomo, la quale in guisa di centauro può riferirsi nella parte superiore, così tutta è bella e virile; o nella inferiore, così tutta difforme e bestiale appare. (53)

Although Zoppio does state that the human soul can contact the angelic mind. he also makes it clear that a man is neither a beast nor an angel, and thus must focus on his "ragione" as the actual kernel of his identity (58). Zoppio is aware that he is betraying the Neoplatonic tradition. Indeed, after having paid his tribute to Ficino's and Plato's philosophy of love, Zoppio writes: "Però lascio Platone su l'ali, e mi abbasso a considerar l'amore secondo noi, in quanto siamo ragionevoli" (59).

In announcing his own theory of love, Zoppio uses an eloquent expression: "mi abbasso" (both "I go down" and "I debase myself"). Indeed, Zoppio's concept of love focuses on love's physicality, on its bodily aspects, rather than on its spiritual or "superior" nature. A basic assumption of Zoppio's discourse is that sexual intercourse is not a negative product of man's "base" instincs, but rather a natural need: 
potrebbe ad alcun parere che la natura istessa abbia posto la beltà nella donna, non perché si miri solamente, come una bella statua e s'inamori l'uomo di lei [...] ma perché ne sia esca a quel diletto al qual fece inclinatissime tutte le specie dei viventi. (62)

In this crucial passage Zoppio reverses Ficino's idea of love, which was based primarily on sight and hearing: "Love regards the enjoyment of beauty as its end. That pertains only to the intellect, to seeing and to hearing" (41). Unlike Ficino, Zoppio underscores the fundamental role played by touch, and thus by carnal intercourse, in every manifestation of love:

il toccare, il che sebbene si faccia con la sommità delle dita, trascorre nondimeno il diletto per tutto il corpo, commuovendo il sangue infin nelle più intime parti delle vene. Succede il baciare, prima leggier e timorosamente, al fine più affettuoso, accompagnato dagli abbracciamenti, per tralasciar di più oltre. (61)

Broaching another central aspect of Neoplatonism, namely its search for harmony through love. Zoppio states that touch grants the lover the perfect form of harmony:

non veggio come sia più soave armonia nella proporzione dei lineamenti di quella che nella corrispondenza degli abbracciamenti, quando braccia a braccia, petto a petto, volto a volto, occhi ad occhi, bocca a bocca, ed ogni parte dell'uomo ad ogni parte della donna con movimento a tempo, come in una benissimo disposta melodia, vengono a corrispondere. (94)

It is evident that, for Zoppio, to love means to love with the body. Where for Ficino love was a private, solitary process of self-enlightenment, for Zoppio it is a natural drive of man's physicality. The technical word "diletto," present in every Neoplatonic treatise, is nothing but physical pleasure in Psafone. ${ }^{3}$ According to Zoppio, marriage is the perfect expression of love because it combines physical and psychological love:

quelli godono compitamente delle delizie d'Amore, che in legittimo modo di matrimonio congiunti, si pascono scambievolmente dei nettari e dell' ambrosie amorose. $\mathrm{O}$ sposi felici, che di reciproco ardore scaldati, si come uniti dell'alme, congiunti dei corpi, s'accolgono dolcemente infra le braccia dilette. (70)

Zoppio's description of the positive effects of physical love may seem much more realistic and modern than Ficino's and Leone Ebreo's. However, it is imperative to keep in mind that for Ficino love is primarily the quintessential form of mysticism and of self-discovery. It is through desire that the Neoplatonic subject moves toward himself. For that matter, Zoppio as well stresses the private nature of love. However, in Zoppio's discourse no process 
of self-invesigation is detectable. Where for Ficino the beloved is the source of our self-discovery, of our inner "grace," for Zoppio the other is exclusively the "place" where the subject's drive can be fulfilled. It is significant that, when he distinguishes among three forms of "amorous union," Zoppio reiterates that every form of love is in fact directed to oneself, to one's personal drive for pleasure (diletto):

Questa unione ha tre gradi, uno che ha ragione di principio prossimo, uno d'atto, ed un altro d'effetto. Il primo è sostanziale in quanto uno ama se stesso, che se bene è una cosa medesima, nondimeno in quanto amante, ed amato ha ragione di due ridotti in uno; è ancora di similitudine in quanto ama altrui. Il secondo è per l'applicazione dell'amante all'amato disposto verso lui, o come verso se stesso, o come verso parte di sé. Il terzo è reale, secondo che l'amante cerca dall'amata l'unione in effetto. (68-69)

The three forms of union share a basic characteristic, that is, their originating from the subject and being directed to the subject. Physical pleasure being the main goal of the subject's desire, it is no surprise that the other, the woman, becomes a prey to be conquered and "enjoyed." Ironically enough, Neoplatonism's stress on beauty is interpreted by Zoppio as the spark that inflames man's sexual drive: "la bellezza per natura antecede l'amore, destando l'appetito all'amore come fine, in quella guisa che l'intellegibile muove l'intelletto" (78). In Zoppio"s discourse terms like "intellegibile" and "intelletto" lose their original connotation. Zoppio in fact makes use of this philosophically charged terminology in order to grant his rather straightforward theory an aura of complexity.

Another cornerstone of Ficino's philosophy is reinterpreted by Zoppio in a literal manner. Ficino, following Plato, speaks at length about love, in particular "Socratic love," as a desire that "gives birth in beauty" (Ficino 57). Zoppio sees the act of giving birth in a totally physical way:

Platone infatti toccò la midolla col definire Amore Desiderio di partorire nel bello, e volse che a questo parto ostetrice e lucina fosse la Bellezza, nel cui grembo gli animi umani a certa età pervenuti, come ai giorni del partorire, dopo lunga gravidanza, producessero la prole, cosa che non possono fare nel brutto, alla cui vicinanza si ristringono, e non valendo a partorire si cruciano [...] lo veggio una bellezza, la desidero in maniera che bramo di fare quelle operazioni nel soggetto di lei capace, che per natura siamo incitati a fare, quando la beltà ci eccita. (79)

In Psafone "to give birth" literally means to inseminate the female partner during sexual intercourse:

[amore è] desiderio non solo del bello, ma di partorir nel bello, il che non si può fare senza il seme, ch'è il naturale istromento all'esprimere tal'amore, essendo quello la forza del generare. (108) 
The subject's desire for beauty brings about his desire for possession of that beauty. It is almost unnecessary to point out that in Psafone the lover is exclusively male. It is also superfluous to underscore that, according to the above passage, carnal love is crucial for the subject because it is through sexual love that a man acquires his status of subject. Love. Zoppio says, is a desire that becomes present when the subject "reaches a certain age."

In several passages Zoppio attacks women because they should be more willing to grant their "graces" to their lovers. For instance he asks: "che stimate voi donne altere, voi dico, che della bellezza vostra invaghite, solo di voi medesme soddisfatte, orgogliose sdegnate gli amanti?" (22) Indeed, the final section of Psafone tackles the topic of the relationship between men and women. To synthesize Zoppio's view on women, it will suffice to mention his eloquent definition: "Le donne sono come le pere giacciuole, bisogna aspettare il tempo del coglierle, e non preterirlo" (214).

Men's attraction toward women is seen by Zoppio as a meaningless, albeit unavoidable, occurrence. In fact, Zoppio agrees with Plato that men's beauty is definitely superior to women's:

Della costituzione del corpo e della proporzione delle membra, quanto alla grandezza molto sarebbe che dire per la parte degli uomini, i quali avvantaggiano in grandezza le donne $[\ldots]$ perché pare che quella sia migliore costituzione, e più bella, che più s'avvicina all'eroica, onde il picciol corpo sarà ben detto grandioso e ben formato, ma propriamente bello no $[\ldots]$ E sovviemmi, s'io non vo tentoni, Platone approvar maggiormente quella bellezza che più s'accosta al virile. (113-14)

Since women cannot attain "heroic" beauty, which is essentially male, women are a "lack:" "La donna, certo, è un mancamento" (139). What could a man ever learn, one might ask, from the female "lack"? It is clear that man must possess the female lack because his sexual drive orders him to do so, even though he, the male subject, does not apprehend anything from his contact with the female body. In neoplatonic thought beauty is a synonym for good and thus for perfection and enlightenment. Zoppio, on the other hand, is unable to make sense of the apparent contradiction between male beauty and male attraction toward women. In other words, (male) beauty loses its philosophical meaning.

To prove that beauty is essentially male, Zoppio mentions the fact that nobody, according to him, would choose to become a woman:

s'intenderà ch'ella desideri, come il brutto il buono, cioè come il manco perfetto il più perfetto, così considerata la donna viene in sembianze di materia rispetto alla forma a desiderar l'uomo, cioè d'informarsi, anzi di trasformarsi (ove far lo potesse) in uomo, e non credo (a dire il vero) che si trovi donna al mondo per bella e amata che sia, a cui se fusse proposto qual delle due cose eleggesse meglio, o '1 restarsi perpetuamente donna, overo da alcuno dispensatore nelle leggi naturali esser ridutta alla perfezion maschile (nel resto pari) non credo, dico, che non eleggesse piuttosto d'esser fatta uomo che di 
rimanersi donna. Ovvero, all'opposto, non mi cade in credenza che si ritrovasse uomo che bramasse giammai diventar donna, se non forse un qualche più ch'effeminato Eliogabalo o bestial Nerone, immeritevole d'esser uomo. (135-36)

If we read this passage carefully, we notice that Zoppio's rhetoric reveals a crucial paradox. Whereas for Plato and Ficino love was a private male discourse, for Zoppio it becomes a female process of self-fulfillment. For Zoppio, a man cannot learn anything from a woman because she is a "mancamento." However, through her relationship with a man, a woman can fill her existential "gap," and thus can become a subject. Every woman, Zoppio believes, would love to become a man, whereas no man, unless he is a "pervert," would like to give up his masculinity.

Desire is sexual desire, according to Zoppio. Consequently, Ficino's efforts to find a higher meaning in love lose their impact in Zoppio's discourse. For Zoppio. love is in fact a constant and meaningless struggle between the male subject, who wishes to fulfill his drive, and the female beloved, who denies him his pleasure. Psafone concludes with a long section on how to seduce a woman. "Bontà e prossimità" (goodness and closeness) are two major elements in every form of seduction (177). Even if he is not honest, man must pretend to be so (178). Moreover, man must pretend to belong to one of those categories that women find the most attractive:

[D]imanderai quali per l'ordinario sono i più favoriti delle donne? Io ti risponderò [...] il primo il nobile, appresso il bello, poi l'eloquente, ultimamente il garbato. Ma il nerbo di tutti, e quello che dà spirito e compimento ad ogni cosa, l'esser ben denaroso, poiché la regina pecunia è atta a donare ogni decoro. E chiunque ha presenti in quantità, costui ha bellezza, ha fortezza, ha eloquenza, ha nobiltà, ha arte, ha prossimità d'inclinazione, ha molte cose più degli altri. (182)

Women do fall in love with noble, beautiful, and well-spoken men, but they never say no to money. Money buys every woman's love. In case of rejection, one may turn to a more understanding lady:

Altro è l'appassionarsi, altro è il procacciarsi qualche ricreazione e solazzo, o per dare la parte sua al senso, o per avere dove sfogarsi quando ci viene impedito l'ottenere quello che bramiamo da altra donna. Approvo io la donna inferiore per questo trattenimento e godimento, come di più facilità e soddisfazione, ma per l'innamoramento io desidero cosa più esquisita. (186)

A final question arises at this point. Is there any relationship between Zoppio's love poems and his treatise on love? What is the connection between the woman described in his verses, that goddess who illuminates the poet's "cloudy" identity, and the woman as object of man's sexual drive? Both Ricreazioni amorose and Psafone must be interpreted as products of two dis- 
tinct literary genres. On the one hand, in the poetic tradition Neoplatonic thought imposes a strict rhetoric, reproduced with no substantial originality. On the other hand, the innumerable trattati d' amore written during the Renaissance debate Ficino's controversial and ambiguous theories. As Psafone clearly shows in its particular interpretation of some Neoplatonic key terms such as "diletto" and "partorire nel bello," in their treatises the Italian authors tend to use the standard technical words and expressions of Platonism and Neoplatonism but with different connotations. Although most of these texts apparently limit themselves to reiterating clichéd ideas, they actually modify the Neoplatonic philosophical discourse by "misusing" its language.

\section{University Of Pennsylvania}

\section{NOTES}

1 One should recall that academies are a fundamental aspect of the Italian Renaissance. As Frances Yates reminds us, "from the academies of fifteenth- and sixteenth-century Italy there sprang the whole vast development of modem intemational academism" (7). Italian academies expressed a strong enthusiasm for Platonic and Neoplatonic thought and attempted to recreate the atmosphere of Plato's Academy (Yates 9). In an ambience of vague and secretive mysticism the 'erudites' gathered in order to produce cultural 'experiences,' verifying and discussing them together (Quondam 827).

2 My forthcoming edition of Malespini's discourse is based on the manuscript at the Van Pelt Library of the University of Pennsylvania in Philadelphia.

3 For instance, in Leone Ebreo's Dialoghi d' amore Filone ("Lover") says to Sofia ("Wisdom"): "Il fine d'ogni amore è il diletto: e il mio è vivacissimo amore, e il fine suo è fruirti con unitiva dilettazione" (387).

\section{WORKS CITED}

Casoni, Guido. Della magia d' amore. Venezia: Zoppini, 1592.

Ficino, Marsilio. Commentary on Plato's Symposium on Love. Trans. Sears Jayne. Woodstock, Connecticut: Spring Publications, 1985.

Garin, Eugenio. Storia della filosofia italiana. 2 vols. Torino: Einaudi, 1966.

Leone Ebreo. Dialoghi d'amore. Bari: Laterza, 1929.

Maggi, Armando. "Della magia d'amore di Guido Casoni quale compendio della trattatistica rinascimentale sull'amore." Revue d'études italiennes 43.1 (1997): 67-77.

—. "Critica del Neoplatismo nell'inedito Ragionamento d'amore di Lorenzo Giacomino de' Tebalducci Malespini." Giornale italiano di filologia 49.2 (1997):1-21.

Maylender, Michele. Storia delle accademie d'Italia. 5 vols. Bologna: Cappelli, 1929.

Quondam, Amedeo. "Le accademie." Letteratura italiana. Ed. Alberto Asor Rosa. 10 vols. 1, I movimenti. Torino: Einaudi, 1982. 824-75.

Ricreazioni amorose degli accademici Gelati di Bologna. Bologna: Rossi, 1590.

Sansovino, Francesco. Ragionamento d'amore. Trattati d'amore del cinquecento. Ed. Giuseppe Zonta. Bari: Laterza, 1912. 151-84.

Tiraboschi, Girolamo. Storia della letteratura italiana. 9 vols. Modena: Società Tipografica, 1772-1782.

Yates, Frances. Renaissance and Reform: The Italian Contribution. London: Routledge, 1983.

Zoppio, Melchiorre. Psafone. Bologna: Rossi, 1590. 